\title{
Western Arabo-Islamophobia: Where and When Will It End?
}

\author{
ABDULSALAM HAMAD ${ }^{1}$
}

\begin{abstract}
Islam has been under intensive ongoing crusade for centuries. It has been made into what might be called the cause of all the problems and ills that afflict the world. Every Westerner with a political axe to grind is being given centre stage to pontificate on Islam. Western political leaders have also adopted an apocalyptic discourse to ratchet up their rhetoric so as to talk in God's name of the holy struggle against evil: Islam. Attacks have, therefore, been carried out against Arabs and Muslims in the West for the one and only simple fact that they are Arabs and Muslims. Islam, in Western eyes, is thus an invalid religion that must be rooted out from the soul of the world. This paper will be seeking to rebut these allegations and claims, prove that the West's blindness to the truth has led it to perceive Islam as incompatible with the principles, prerequisites, and civil ethics of the Western world, and with the world at large. and provide evidence that it was under the sky of Islam that the human mind had most fully flourished and developed some of its choicest gifts, had most deeply pondered on the greatest problems of life, and had found solutions for some of them which deserved the attention even of those who studied Plato and Kant. Ultimately, it will be illustrating that it is time to come out of the narrow shell of misrepresentation, hostile and oriental stereotype, parochialism and communalism, religious rancour, and politics, and illuminate the track of humanity by holding high the lamp of wisdom, by giving form and shape to the great and noble dreams that were cherished by the immortal prophets and philosophers of the past so that the whole world might declare that the light has come from the East and saved the West from doom and destruction.
\end{abstract}

Keywords: Arabophobia, communalism, Islamophobia, parochialism, the West

The deep-seated Islamophobia undeniably harks back to many centuries of denigrating, and othering Islam. It has taken different forms at different times and in different contexts. From the Spanish Reconquista to the Crusades, and from the colonial wars to post-coloniality, Islam has been the archetypical enemy of the West, the demonised Other. This long-standing mental construct of Arabs and Islam in the depth of the Western psyche stems from manifold reasons that will be explained later. Hence, it is not unexpected that Islam has currently been made into what Kabbani (1986) once called, "the religion the West loves to hate ... and a dumping ground for all blame (italics mine)." Every day, as Ali Bulaç (12 June 2009) in Why is Islam in conflict with the West? notes, the Muslim world confronts "a new definition and another campaign for defamation: fanaticism, fundamentalism, political Islam, integrism, radicalism, Islamophobia, Islamofascism, reactionaryism, conservatism, extremism, Islamic terror, etc."

\footnotetext{
${ }^{1}$ Abdulsalam Ali Hamad, Ph.D., assistant professor at Department of English Language, Faculty of Arts and
} Humanities, Al-Baath University, P.O. Box: 77, HOMS, Syria, email: abdulsalamhmd@gmail.com. 
Arabo-Islamophobia, as Said (1978), Kabbani (1986), and Chahuan (2005) point out, can be attributed to a set of imperialistic designs that emanates from a colonial past. "The prejudices of today," aptly contends Chahuan, for instance, "preserve and perpetuate the falsehoods of the past. The European colonial aggression in the Arab countries during the XIX and XX centuries have been justified by a series of arguments whose common denominator was the depreciation of the Other, and the negative view of the Arabs today is an extension of the imperialist attitudes of a past not so far away."

In contrast, Keegan, the defence correspondent of the Daily Telegraph (October 2001), Bernard Lewis and Samuel Huntington and their ilk, maintain that it is a "clash of civilizations," (Esposito 1999: 230). But President Bush goes on so far as to claim that it is "a struggle for civilization." Bush's address to the nation (September 11, 2006) reveals the perverse logic of Islamophobia today:

The war against this enemy is more than a military conflict. It is the decisive ideological struggle of the 21st century, and the calling of our generation ... This struggle has been called a clash of civilizations. In truth, it is a struggle for civilization. We are fighting to maintain the way of life enjoyed by free nations.

Pope Benedict XVI also asserts this in his speech (September 12, 2006), as he equates Catholicism with reason and Islam with violence and the lack of reason. Paraphrasing a fourteenth century Byzantine emperor, he stated that when a religion (like Islam) is spread through violence it goes against reason, and also against nature, for "not to act in accordance with reason is contrary to God's nature."

In Islamic Thinking in Limbo, published in the Higher Education section of the Australian on October 25, 2006, Riaz Hassan also alleges that Islam imprisons "a significant proportion of humanity into permanent servitude..." and that "science is the weakest in the lands of Islam." Hassan also assumes that the consequential dangers of this "weakness" are devastating. Besides, he claims that "Muslim countries are increasingly coming under intense pressure from religious fundamentalists to impose epistemologies comparable with their versions of Islamic doctrines that are generally hostile to critical rational thought." Furthermore, he alleges that "most causes of Muslims' present predicament can also be attributed to prevailing culture and political practices," and that in his "recent studies of contemporary Islamic consciousness in some Middle Eastern Muslim countries," he "was struck by an all-pervasive sense of humiliation... This sense of humiliation," as he claims, "is a key underlying cause of Islamic militancy and terrorism."

Hassan then concludes that "A robust civil ethic is a prerequisite for developing a society based not on the tyranny of strongly held convictions but on a social order based on reason and compromise. Science and technology prosper only under conditions that privilege the rule of reason and nature. The influence of religious fundamentalist movements is having a deleterious effect on academic conditions, especially in the humanities and social sciences." Such anti-Islamic views are adequate enough to demonstrate that Arabo-Islamophobia is in full flower, and their poisonous petals of perverted hatred are blooming all around us. They are also illustrative that Muslimbashing post-colonial orientalists, like Riaz Hassan, for instance, are evidently going to make it what might be called, in effect, a mainstream in Western thought by coating it with more scholarly façade. Indeed, the number of inarguably Islamophobic books, articles, films, and cartoons that has recently been unleashed is sufficient to substantiate this and fan the flames of hate in Western thought. 
Further examples are in fact numerous, but to randomly mention a few of them might suffice it to say that the "clash of civilisations" is on the horizon. The nomination of Bruce Bawer's While Europe Slept: How Radical Islam is Destroying the West from Within (2006), for instance, by the highest literary circles: the National Book Critics Circle (NBCC) in February 2007, is emblematic of this mainstreaming. The other example is the publication of Orianna Fallaci's The Force of Reason (2004), Robert Spencer's two Times bestsellers, The Politically Incorrect Guide to Islam and the Crusades (2005) and The Truth About Muhammad: Founder of the World's Most Intolerant Religion (2006), Mark Steyn's New York Times bestseller America Alone: The End of the World as We Know It (2006), and Melanie Phillips' Londonistan (2006). Further, the documentary, Obsession: Radical Islam's War Against the West (2006), which depicts "Islam as a menace threatening, with all the means at its disposal, to bow Western civilization under the yoke of its values," is but one more example cited in this context (quoted in Steve Rendall and Isabel Macdonald (November/December 2008).

Western movies also play a no less obnoxious role in disseminating this global AraboIslamophobic phenomenon than electronic and printed media, "especially when they are in the service of colonial interests, military and economic expansionist ideologies, or a vehicle for the promotion of Western values" (Chahuan 2005). The image of Muslim Arabs projected by Western movies, as Shaheen (2000) observes, is often that of "money-grubbing caricatures that sought world domination, worshipped a different God, killed innocents, and lusted after blond virgins." The derogatory cartoons by the Danish cartoonist in Jyllands Posten, are also but a further symptom of this mainstream.

This might sound flabbergasting, but what is more flabbergasting is that, in 2004, a highly popular American radio host, Michael Savage, depicted Arabs as "non-humans, racist, and fascist bigots." Savage overtly claimed that Americans want the US to "drop a nuclear weapon" on an Arab country, and advocated that people in the Middle East must be "forcibly converted to Christianity" to "turn them into human beings."

This Western orchestrated Arabo-Islamophobic propaganda is indicative enough that the West cannot exist without an enemy even if it were imaginary. After the demise of the Soviet bloc, the West had needed an enemy to seek to justify its global hegemony and imperialistic designs in the Middle East. Therefore, after Bush's "Axis of Evil" had replaced Reagan's "Evil Empire", Islam was immediately conjured up as its new global opponent to serve this role. Since then, the West has unleashed with all ferocity the largest enterprise of falsification ever witnessed by human history to entirely warp the concepts and notions of Islam as a religion, a culture, a history, a civilisation, and a nation.

The distorted perception of the Arab and Muslim world and the stereotypical features attributed to it are also explicitly meant to give rise to a monolithic view of the Arabs and the Muslims among the political community, the media, and the world of academe so as to negate the rich cultural and scientific heritage of these people and their contribution to Western civilisation. As is known, the West would not have gone through its renaissance had it not been for the contributions made by the Arabs and Muslims. The West's animus toward Arabs and Islam, thus, stems from the denial of its true lineage. The Western civilisations, and languages were indubitably fathered by Islam. In Deep Roots of Islamophobia, Brooks (2003), for instance, explicitly affirms this:

We learned "our" Greek heritage by translating the Arabic translation into Latin. For centuries, the fundamental texts of budding European scholarship were based on Arabic translation, and Europe's scholarship continued to be informed by its more learned Arab contemporaries. Europeans even copied Principles of Islamic 
scholarship and academic organization in building their own nascent academics. But soon we were spinning the myth that we'd got it all directly from "our" Greek ancestors.

Furthermore, in a lecture delivered at the Oxford Centre for Islamic Studies in 1993, British Crown Prince Charles outspokenly asserts, "Islam is part of our past and our present, in all fields of human endeavour. It has helped to create modern Europe. It is part of our own inheritance, not a thing apart". In the same vein, the late British Foreign Secretary, Robin Cook, in a lecture given at a centre in London in 1998, openly states, "The roots of our culture are not just Greek or Roman in origin, but Islamic as well. Islamic art, science and philosophy have helped to shape who we are and how we think. Islam laid the intellectual foundations for large portions of Western civilization."

Thus, to expunge the memories of that heritage, "to pervert history, emphasize Arab regression, deny Arab culture, and generally be hostile to all things Arab" (Suleiman 2003), the West has even latinised the names of Arab and Muslim scholars and scientists so as to blot out of Western history the contributions of those Muslim torchbearers to Western civilisation. The following table shows only some of those Arab and Muslim scholars, whose names were Latinized so as to sound Western.

\begin{tabular}{|l|l|}
\hline \multicolumn{1}{|c|}{ English/Latin Name } & \multicolumn{1}{c|}{ Latinised/English Name } \\
\hline Jabir Ibn Haiyan & Geber \\
\hline Al-Khawarizmi & Algorism, Algorithm \\
\hline Al-Kindi & Alkindus \\
\hline Al-Battani & Albategnius \\
\hline Al-Farghani & Al-Fraganus \\
\hline Al-Razi & Rhazes \\
\hline Al-Farabi & Al-Pharabius \\
\hline Abu Al-Qasim Al-Zahravi & Albucasis \\
\hline Al-Haitham & Alhazen \\
\hline Abu Al-Hasan Al-Mawardi & Alboacen \\
\hline Ibn Sina & Avicenna \\
\hline Ibn Zuhr & Avenzoar \\
\hline Ibn Rushd & Averroes \\
\hline Al-Zarqali & Arzachel \\
\hline Al-Bitruji & Alpetragius \\
\hline Al-Sufi & Azophi \\
\hline Ibn Bajah & Avempace \\
\hline Ali Abbas & Hale Abbas \\
\hline
\end{tabular}

Finally, the West will never cease its sustained effort to devise in order to rule the Muslim World, especially the Middle East, and loot its wealth and resources, oil, in particular. However, the heights that Arabo-Islamophobia has reached are undoubtedly unprecedented. One of its living examples is the too colossal and too wasteful a tragedy enacted in Iraq under the cloak of democratisation. It is indeed too terrible to contemplate. The United States and its European allies there have killed scientists and academicians, destroyed universities, schools, libraries, museums, all infrastructure, built nothing but tombs, sent one million to death, in the least, plunged myriads of homes into desolation and misery, multiplied orphans: five millions, and widows: one million, refugees: six millions, left behind a long trail of misery, starvation and sickness, destroyed the 
strongest and the healthiest of the population, and left the sick, the puny, and weaklings to be the fathers of the next generations.

They have also brought about a serious moral degeneration of the masses, imprisonment of simple people, and pitilessly diminution of their humanity. Furthermore, murder is still applauded there, and mercy is made a thing of lies, and is openly recommended. People have been robbed of their decency, of happiness and of life itself. Hence, mass murder, spiritual death, total destruction, lack of the simplest human rights, and the deliberate and persistent propagation of hatred and falsehood, are the progeny of that Arabo-Islamophobia.

These allegations and charges are undoubtedly indicative enough of Arabo-Islamophobes' crass ignorance of history, of their lack of critical intellectual examination, of their lack of sound perception, and of their lack of awareness of the importance of Islam's past contribution to Western civilisation. Their blindness to the truth has led them to perceive Islam as incompatible with the principles, prerequisites, and civil ethics of Western world, and with the world at large.

Indeed, it is odd and deplorable enough that such intellectuals are more concerned with the husk than with the grain of truth. As intelligentsia, they should have been, at least, objective, dispassionate, transparent, unbiased, and truthful in their contention and findings. Instead, they tend to shut eyes to the truth that of all the religions in the world Islam has the richest treasurehouse of culture and civilisation, and that Islam has been the spiritual and physical nurse and guide of humanity at large.

Long before any European civilisation took any tangible shape, Islam and the Arabs were on the zenith of glory. There was no shape of human activity in which they did not claim to their credit splendid triumphs, and such noble achievements as could not wither with the lapse of time. Hence, they are either entirely ignorant of this treasure or they deliberately turn their backs upon it and fabricate such packages of allegations.

In Islam, knowledge is noor i.e. light. Hence, Islam makes the pursuit of knowledge a form of religious obligation. "Seek learning as far as China," asserted Prophet Muhammad. That pursuit of knowledge is also not confined to a particular field of inquiry or discipline, but it must cover all dimensions of human awareness and the entire spectrum of natural phenomena. Moreover, Quran means that which is read, recited, rehearsed. In fact, the very first revelation directed the Prophet: "Recite in the name of thy Lord Who created everything. He created man from a clot of blood. Recite, for thy Lord is Most Beneficent, Who has taught by the pen, taught man that which he knew not" (al-Quran, al-'Alaq, 96:2-6). Therefore, Islamic scholars have, over ages, been engaged zealously in generation, production, processing and dissemination of knowledge.

However, Arabo-Islamophobes do not know that it was the Muslims who sparked the light of learning and productivity and without whom the European Renaissance would not have begun and come to maturity. It suffices, here, to evoke a few glorious names of those Muslims: Jabir ibn Haiyan, al-Kindi, al-Khawarizmi, al-Fargani, al-Razi, Thabit ibn Qurra, al-Battani, Hunain ibn Ishaq, al-Farabi, Ibrahim ibn Sinan, Al-Masudi, Al-Tabari, Abul Wafa, 'Ali ibn Abbas, Abul Qasim, Ibn alJazzar, Al-Biruni, Ibn Sina, Ibn Yunus, Al-Kashi, Ibn Al-Haitham, 'Ali ibn 'Issa Al-Ghazali, Al-Zarqab, Omar Khayyam. A magnificent array of names which it is not difficult to extend.

They do not also know that numerous serious thinkers and mature minds of the West have paid very high attention to the message of Islam and Islamic culture. To mention some of those luminaries would suffice here: George Sarton (1927, 1950); Robert Briffault (1938); Thomas Arnold (1960); T. Arnold and A. Guillaume (1931); E.G. Brown (1921); D. Campbell (1926); P.K. Hitti (1956), E. Gibbon (1900); De Lacy O'Leary (1922); Bertrand Russell (1948); Thomas Carlyle (1840); Carra de Vaux (1921), etc. 
It is not difficult to extend this cluster of Western luminaries who proudly acknowledged Western civilisational debt to the Muslims and the Arabs. For instance, "I have to deplore the systematic manner," wrote Draper (1904), "in which the literature of Europe has continued to put out of sight our obligations to the Muhammadans. Surely they cannot be much longer hidden. Injustice founded on religious rancour and national conceit cannot be perpetuated forever. The Arab has left his intellectual impress on Europe. He has indelibly written it on the heavens as anyone may see who reads the names of the stars on a common celestial globe."

The well-known early 12th century Englishman, Adelard of Bath, also often enthusiastically admitted his debt to the Arabs - "trained", as he says, "by Arab scientists ... I was taught by my Arab masters to be led only by reason, whereas you were taught to follow the halter of the captured image of ancient authority [i.e., authority of the Church]" (cited in Stiefel (1989: 71, 80). This high attention is obviously based on the sound judgment of those Western scholars, thinkers and critics who have delved deep into the wisdom of Arabs and have unreservedly expressed their appreciation of Islam and Islamic culture.

Moreover, Shaw (1936) explicitly asserted, "I have always held the religion of Muhammad in high estimation because of its wonderful vitality. It is the only religion which appears to me to possess that assimilating capacity to the changing phase of existence which can make itself appeal to every age. I have studied him - the wonderful man and in my opinion far from being an antiChrist, he must be called the Savior of Humanity." Shaw also believed that if Muhammad assumed the rule of the "modern world, he would succeed in solving its problems in a way that would bring it the much needed peace and happiness: I have prophesied about the faith of Muhammad that it would be acceptable to the Europe of tomorrow as it is beginning to be acceptable to the Europe of today."

Similarly, Wells (1922) maintained that "The Islamic teachings have left great traditions for equitable and gentle dealings and behavior, and inspire people with nobility and tolerance. These are human teachings of the highest order and at the same time practicable. These teachings brought into existence a society in which hard-heartedness and collective oppression and injustice were the least as compared with all other societies preceding it ... Islam is replete with gentleness, courtesy, and fraternity."

Hitti, likewise, (1956) averred that "... no other people made as important a contribution to human progress as did the Arabs, if we take this term to mean all those whose mother-tongue was Arabic, and not merely those living in the Arabian peninsular. For centuries, Arabic was the language of learning, culture and intellectual progress for the whole of the civilized world with the exception of the Far East. From the IXth to the XIIth century there were more philosophical, medical, historical, religious, astronomical and geographical works written in Arabic than in any other human tongue."

Even Napoleon Bonaparte, too, declared, "I hope the time is not far off when I shall be able to unite all the wise and educated men of all the countries and establish a uniform regime based on the principles of Quran which alone are true and which alone can lead men to happiness" (cited in Cherfils 1914: 105, 125).

It was thus under the sky of Islam that the human mind has most fully flourished and developed some of its choicest gifts, has most deeply pondered on the greatest problems of life, and has found solutions for some of them which will deserve the attention even of those who studied Plato and Kant. Arabo-Islamophobes' ignorance has also been more exposed when they have attributed fundamentalism and militancy to Islamic-Arabic culture. As highly educated people, they should have known that the Arabic word for culture is thaqafa, taken from a root which means to purify, to transform, to sublimate, to mould and to perfect. A cultured man is a disciplined man who 
has brought his natural instincts under control and has shaped himself in accordance with the ideal placed before him by his moral consciousness.

Islamic culture is a human culture. It is tried to be so comprehensive as to suit the need of time and circumstances, as well as the needs of every human being, irrespective of age, sex, colour or race. As such it has a universal appeal. Islamic basic principles are thus so broadbased that they can be adapted to almost any environment and development. Its superstructure may change from time to time, but its inner contents remain constant and enduring. It is for this reason that Islamic culture has retained its true spirit through shocks of centuries, hundreds of foreign invasions to root it out from the soul of the world, and thousands of social and political upheavals.

In Islam, mutually contradicting opinions can and do keep the world together without any quarrel with the other cultures, and because of the ingrained conclusiveness, its tolerance, and its indifference to doctrinal divergences underpin the essential unity of all human beings and minimise differences. This tolerance of differences of opinion and ideas within its own fold and outside itself is an essential characteristic of Islamic culture.

Of equal importance, Arabo-Islamophobes also do not know the difference between humiliation and humility. Muslims have a sense of humility, a deep awareness of human frailty, but not humiliation. They have, therefore, charity for all and malice towards none. With everything whether it is above or below, remote or near, visible, or invisible, a Muslim preserves a relation of unlimited love without any animosity or without a desire to kill. This is the teaching of Islam and the crux of Arabic culture.

Furthermore, they do not know that Islam means peace to all living creatures, and that love, truth, mercy, sympathy, tolerance, catholicity, as well as liberal adjustment to others' creed and opinion, and sacrifice are but a part of the glorious message of Islam. All Muslims believe that all the diverse doctrines and paths originating at different times and different countries, however, lead ultimately to the same Supreme Truth, like the many different paths leading travellers from different places to the same city. To put another way, Muslims believe that flame is the same even though the types of fuel may vary, and, again, even as the several sages discern the different qualities of one object, so also the different scriptures indicate the many aspects of the one Supreme.

The tolerance of Islamic culture has become a philosophy according to which the reality, and every expression of it has innumerable aspects and every thinker views it from one or the other aspect, and therefore, his view and judgment about the same object are bound to differ from those of others who look upon the object from another angle of vision. It is a very healthy principle to remember that our judgments are partial truths and can never be absolutely true.

It is on account of this catholicity and this humility which characterise Islamic-Arabic culture that religious, doctrinal, philosophical and ideological differences among people and nations have not tended to mar the general advancement of the cultural life of any country. Whatever the political, linguistic, racial and religious differences between the various parts of the country, one never fails to find a common culture flourishing in all over the Islamic world. Hence, AraboIslamophobes should have remembered that all the discordant notes ultimately bring about greater and greater harmony.

Besides, because Islamic culture is not indifferent to foreign elements, it has grown vigorous in every age by absorbing all that was best in the culture with which it came into contact. In ancient times, there was much give and take between the Arabs and the Greeks and other nations. In medieval times it made its own all that was best in Islamic culture. And now in modern times, slowly and gradually Islamic culture is absorbing all that is best in the scientific civilisation of the 
West, without losing any of its vital elements. Islam thus fuses all different cultures into one harmonious whole.

Ultimately, it is time to come out of the narrow shell of misrepresentation, hostile and oriental stereotype, parochialism and communalism, religious rancour, and politics, and illuminate the track of humanity by holding high the lamp of wisdom, by giving form and shape to the great and noble dreams that were cherished by the immortal prophets and philosophers of the past so that the whole world might declare that the light has come from the East and saved the West from doom and destruction. It is also time to free ourselves from all ill-will against all beings at all times and in all ways.

Furthermore, the notion of a "clash of civilisations" and cultural relativism must be totally rejected. It is much more useful to emphasise the cultural metabolism, the exchanges and emulation that have tied both "East" and "West" for centuries. Dialogue and peaceful coexistence must be cherished as precious goals and as guiding principles in the interaction between the Muslim world and the West, bearing in mind that all human beings are made equal from the same jewel. We must also remember that the world is not merely a battlefield in which the weak are exterminated by the strong. It is also a school for progress, a classroom for socialisation, a platform for inculcating the lessons of longevity, intelligence, companionship, charity, sympathy, tolerance and love.

\section{References}

Arnold, T. 1960. The Legacy of Islam. London: Oxford University Press.

Arnold, T. \& Guillaume, A. 1930. The Legacy of Islam. London: Oxford University Press.

Bawer, B. 2006. While Europe Slept: How Radical Islam is Destroying the West from Within. New York: Doubleday.

Briffault R. 1938. The Making of Humanity. London: G. Allen \& Unwin Ltd.

British Crown Prince Charles. 1993. In a lecture he delivered at the Oxford Centre for Islamic Studies.

Brooks, J. 2003. Deep Roots of Islamophobia. http://www.mediamonitors.net/jamesbrooks10.html [Retrieved February 3, 2010].

Brown, E.G. 1921. Arabian Medicine. London: Cambridge.

Bulaç, Ali. 2009. Why is Islam in Conflict with the West? http://www.todayszaman.com/tzweb/columnists-177816-why-is-islam-in- conflict-with-the-west.html [Retrieved February, 21, 2010].

Bush, W. G. 2006. President's Address to the Nation, September 11, 2006. http://www.whitehouse.gov/news/releases/2006/09/20060911-3.html [Retrieved February 5, 2010].

Campbell, D. 1926. Arabian Medicine and its Influence on the Middle Ages. London: Kegan Paul.

Carlyle, T. 1840. Heroes, Hero Worship, and the Heroic in History. Lecture 2. Friday, 8th May.

Chahuan, E. 2005. An East-West Dichotomy: Islamophobia. Palestine-Israel Journal of Politics, Economics and Culture. Vol. 12. No. 2\&3. Reprinted in Hillel Schenker, Ziad Abu Zayyad, eds. 2006. Islamophobia and anti-Semitism. Princeton: Markus Wiener Publishers. http://pij.org/details.php?id=346 [Retrieved February 12, 2010].

Cherfils, C. 1914. Bonaparte et Islam. Pedone (ed.). Paris: n.p. pp. 105, 125.

Cook, R. 1998. The late British Foreign Secretary, in a lecture given at a centre in London.

De Vaux, C. 1921. The Philosophers of Islam. Paris: n.p.

Draper, J. W. 1904. History of the Intellectual Development of Europe. London: Harper \& Row. 
Esposito, J. L. 1999. The Islamic Threat: Myth or Reality. 3rd edition. New York: Oxford University Press.

Gibbon, E. 1900. Decline and Fall of Roman Empire. London: Strahan \& Cadell.

Hassan, Riaz. 2006. Islamic Thinking in Limbo. The Higher Education Section of the Australian. October 25.

Hitti, P.K. 1956. History of Arabs. London: Macmillan.

Kabbani, R. 1994. Imperial Fictions: Europe's Myths of Orient. London: Macmillan Press.

Keegan, J. 2001. In this war of civilisations, the West will prevail. The Daily Telegraph. 8 October. O'Leary, De Lacy. 1922. Arabic Thought in History. London: Kegan Paul.

Pope Benedict XVI. 2006. Lecture of the Holy Father. http://news.bbc.co.uk/2/shared/bsp/hi/pdfs/15_09_06_pope.pdf [Retrieved Feb. 12, 2010].

Rendall, S. \& Isabel M. 2008. Making Islamophobia Mainstream: How Muslim-Bashers Broadcast Their Bigotry. http://www.fair.org/index.php?page=3648 [Retrieved Feb. 10, 2010].

Russell, B. 1948. History of Western Philosophy. London: Routledge.

Said, E. 1978. Orientalism, London: Routledge \& Kegan Paul.

Sarton, G. 1927. Introduction to the History of Science. Baltimore: Williams and Wilkins.

Savage. M. 2004. http://mediamatters.org/research/200405140003.

Shaheen, J. G. 2000. Hollywood's Muslim Arabs. The Muslim World. 90 (1-2): 22-42.

Stiefel, T. 1989. The Intellectual Revolution in Twelfth Century Europe. N.Y.: St. Martin's Press.

Suleiman, Yasir. 2003. The Arabic Language and National Identity: A Study in Ideology. London: Edinburgh University Press.

Wells, H.G. 1922. A Short History of the World. London. http://www.amaana.org/ISWEB/legacy.htm [Retrieved Feb. 8, 2010]. 